\title{
Hepatic disorder in Zika virus infection
}

\author{
Viroj Wiwanitkit ${ }^{1,2,3,4}$ \\ ${ }^{1}$ Department of Tropical Medicine, Hainan Medical University, Haikou 571199, Hainan, China. \\ ${ }^{2}$ Department of Medicine, Faculty of Medicine, University of Nis, 18000 Nis, Serbia. \\ ${ }^{3}$ Department of Biological Science, Joseph Ayobabalola University, Ikeji-Arakeji 233121, Nigeria. \\ ${ }^{4}$ Department of Community Medicine, Dr. DY Patil Medical University, Pune 411018, Maharashtra, India.
}

\begin{abstract}
Zika virus infection is the present global problem. This arbovirus infection can cause acute illness and affect fetus in utero. However, there can be other additional clinical manifestation including to the hepatic disorder. In this short commentary article, the author briefly discusses on the liver problem due to Zika virus infection.
\end{abstract}

Key words: Zika virus; liver disorder; infection

\section{Corresponding Author:}

Prof. Viroj Wiwanitkit, Wiwanitkit House, Bangkhae, Bangkok 10160, Thailand. E-mail: wviroj@yahoo.com

Received: 31-05-2016, Accepted: 02-06-2016

\section{INTRODUCTION}

Zika virus is an arbovirus that can cause acute febrile illness. At present, it is the big public health threat. ${ }^{[1]}$ The infection can be serious and can cause neurological complication. In addition, the serious effect on development of fetus in utero can be seen. Hence, World Health Organization document Zika virus infection as an important problem that needs urgent attention and management. ${ }^{[2]}$

Briefly, Zika virus infection can cause a dengue like illness and can be easily misdiagnosed..$^{[3]}$ The acute hemorrhagic fever can be the first presentation of Zika virus infection. Nevertheless, there can be other atypical manifestations. The atypical clinical manifestations can add difficulty in diagnosis of the Zika virus infection. Of several atypical clinical problems, liver disorder can be seen and this is an issue that is less mentioned. In this short commentary, the authors discusses on the liver disorder seen in Zika virus infection.

\section{EVIDENCE OF LIVER DISORDER IN ZIKA VIRUS INFECTION}

There are limited reports on liver pathology in Zika virus infection. Most reports showed no abnormality in liver. In

\begin{tabular}{|l|c|}
\hline \multicolumn{2}{|c|}{ Access this article online } \\
\hline \multirow{2}{*}{ Website: } & Quick Response Code \\
\hline http://www.hrjournal.net/ & \\
\hline & \\
DOI: &
\end{tabular}

the clinical report of new epidemics, Deng et al..$^{[4]}$ and Zheng et al..$^{[5]}$ mentioned for no abnormal liver function in infected cases. In infected death fetus, the molecular pathology also revealed no observed virus in liver tissue. ${ }^{[6]}$ However, there was an interesting report at the time when the Zika virus had just been discovered by Macnamara that Zika virus could be isolated from the cases presenting with jaundice during the outbreak of jaundice in Africa. ${ }^{[7]}$ In addition, the recent animal mice model study revealed that the Zika virus RNA can be seen in Zika virus infected mice. ${ }^{[8,9]}$ In fact, Zika virus is usually included in differential diagnosis of acute febrile illness due to arbovirus infections including to yellow fever: ${ }^{[10]}$ Hence, the question whether there is any interrelationship between Zika virus infection and liver pathology is still a topic for further research.

\section{CO-INFECTION WITH HEPATITIS VIRUS: A TOPIC THAT IS STILL A MYTH}

Finally, it should be noted that Zika virus can be concomitantly seen with other infections (such as dengue ${ }^{[11]}$ and human immunodeficiency virus ${ }^{[12]}$ ). In hepatology, the topic that is still a myth is the concomitance between Zika virus infection and viral hepatitis. Although there has never been report on this issue, it is no doubt that the co-infection already occurred in many tropical countries that presently have the problem of Zika virus epidemic. How the Zika virus infection superimpose

This is an open access article distributed under the terms of the Creative Commons Attribution-NonCommercial-ShareAlike 3.0 License, which allows others to remix, tweak, and build upon the work non-commercially, as long as the author is credited and the new creations are licensed under the identical terms.

For reprints contact: service@oaepublish.com

How to cite this article: Wiwanitkit V. Hepatic disorder in Zika virus infection. Hepatoma Res 2016;2:203-4. 
to viral hepatitis and how viral hepatitis superimpose to Zika virus infection is another topic for further research.

\section{ZIKA VIRUS, CHRONIC LIVER PROBLEM AND HEPATOMA}

An important concern is on the Zika virus infection in the cases with underlying chronic liver problem. As already noted, the evidence on liver pathology in Zika virus infection is extremely limited. For the affect fetus, the recent investigation showed no liver problem. ${ }^{[13]}$ In fact, the relationship between Zika virus infection and cancer is very interesting. Recently, Benelli et al. ${ }^{[14]}$ noted that "basic epidemiological knowledge on the relationships occurring between mosquito vector activity and the spread of cancer is urgently needed, as well as detailed information about the ability of Culicidae to transfer viruses or tumor cells among hosts over time." Nevertheless, the long term followup of Zika virus affected patients, especially for those with underlying chronic hepatitis is suggested. The observation on the possible emerging hepatoma among these cases is recommended.

\section{CONCLUSION}

It is still inconclusive on the exact effect of Zika virus infection on human liver. The further research on this area is recommended for hepatologists.

\section{Financial support and sponsorship} Nil.

\section{Conflicts of interest}

There are no conflicts of interest.

\section{REFERENCES}

1. Chen HL, Tang RB. Why Zika virus infection has become a public health concern? J Chin Med Assoc 2016;79:174-8.
2. Gulland A. Zika virus is a global public health emergency, declares WHO. BMJ 2016;352:i657.

3. Wiwanitkit S, Wiwaitkit V. A febrile, asymptomatic and nonthrombocytopenic Zika virus infection: don't miss it! Asian Pac J Trop Med 2016;9:513.

4. Deng Y, Zeng L, Bao W, Xu P, Zhong G. Experience of integrated traditional Chinese and Western medicine in first case of imported Zika virus disease in China. Zhonghua Wei Zhong Bing Ji Jiu Yi Xue 2016;28:106-9.

5. Zheng CG, Xu Y, Jiang HQ, Yin YX, Zhang JH, Zhu WJ, Liang XJ, Chen MX, Ye JW, Tan LM, Luo D, Gong ST. Clinical analysis of two cases of imported children Zika virus infection in China. Zhonghua Er Ke Za Zhi 2016;54:375-8.

6. Sarno M, Sacramento GA, Khouri R, do Rosário MS, Costa F, Archanjo G, Santos LA, Nery N Jr, Vasilakis N, Ko AI, de Almeida AR. Zika virus infection and stillbirths: a case of hydrops fetalis, hydranencephaly and fetal demise. PLoS Negl Trop Dis 2016;10:e0004517.

7. Macnamara FN. Zika virus: a report on three cases of human infection during an epidemic of jaundice in Nigeria. Trans $R$ Soc Trop Med Hyg 1954;48:139-45.

8. Dowall SD, Graham VA, Rayner E, Atkinson B, Hall G, Watson RJ, Bosworth A, Bonney LC, Kitchen S, Hewson R. A Susceptible Mouse Model for Zika Virus Infection. PLoS Negl Trop Dis 2016;10:e0004658.

9. Zmurko J, Marques RE, Schols D, Verbeken E, Kaptein SJ, Neyts J. The viral polymerase inhibitor 7-deaza-2'-c-methyladenosine is a potent inhibitor of in vitro Zika virus replication and delays disease progression in a robust mouse infection model. PLoS Negl Trop Dis 2016;10:e0004695.

10. Chippaux A, Chippaux-Hyppolite $\mathrm{Cl}$, Monteny-Vandervorst $\mathrm{N}$, Souloumiac-Deprez D. Several yellow fever cases in an endemic area in Ivory Coast: serological and epidemiological evidence. Med Trop (Mars) 1981;41:53-61.

11. Dupont-Rouzeyrol M, O'Connor O, Calvez E, Daurès M, John M, Grangeon JP, Gourinat AC. Co-infection with Zika and dengue viruses in 2 patients, New Caledonia, 2014. Emerg Infect Dis 2015;21:381-2.

12. Calvet GA, Filippis AM, Mendonça MC, Sequeira PC, Siqueira AM, Veloso VG, Nogueira RM, Brasil P. First detection of autochthonous Zika virus transmission in a HIV-infected patient in Rio de Janeiro, Brazil. J Clin Virol 2016 ;74:1-3.

13. Culjat M, Darling SE, Nerurkar VR, Ching N, Kumar M, Min SK, Wong $\mathrm{R}$, Grant L, Melish ME. Clinical and imaging findings in an infant with Zika embryopathy. Clin Infect Dis 2016; DOI: 10.1093/cid/ciw324.

14. Benelli G, Lo Iacono A, Canale A, Mehlhorn H. Mosquito vectors and the spread of cancer: an overlooked connection? Parasitol Res 2016;115:2131-7. 